\title{
NEXTorch: A Design and Bayesian Optimization Toolkit for Chemical Sciences and Engineering
}

\author{
Yifan Wang, ${ }^{1,2 \dagger}$ Tai-Ying Chen, ${ }^{1,2 \dagger}$ and Dionisios G. Vlachos ${ }^{1,2^{*}}$
}

${ }^{1}$ Department of Chemical and Biomolecular Engineering, 150 Academy St., University of Delaware, Newark, Delaware 19716, United States

${ }^{2}$ Catalysis Center for Energy Innovation, RAPID Manufacturing Institute, and Delaware Energy Institute (DEI), 221 Academy St., University of Delaware, Newark, Delaware 19716, United States

†These authors contributed equally.

*Corresponding author: vlachos@udel.edu

\section{Comparison of existing Python-based Bayesian Optimization or kriging packages}

Table S1. Existing Python-based Bayesian Optimization or Kriging Packages.

\begin{tabular}{|c|c|c|c|c|}
\hline Name & Scalability & Flexibility & $\begin{array}{l}\text { Features towards } \\
\text { chemical applications }\end{array}$ & Remarks \\
\hline Spearmint $^{1}$ & $\begin{array}{l}\text { Parallelization is } \\
\text { possible but not } \\
\text { implemented }\end{array}$ & $\begin{array}{l}\text { Provides a variety of } \\
\text { acquisition } \\
\text { functions }\end{array}$ & None & $\begin{array}{l}\text { Among the first } \\
\text { libraries to make BO } \\
\text { accessible }\end{array}$ \\
\hline Dragonfly $^{2}$ & $\begin{array}{l}\text { Supports } \\
\text { parallelization and } \\
\text { handles high- } \\
\text { dimensional } \\
\text { problems }\end{array}$ & $\begin{array}{l}\text { Supports multi- } \\
\text { fidelity, multi- } \\
\text { objective; provides a } \\
\text { variety of } \\
\text { acquisition } \\
\text { functions }\end{array}$ & None & $\begin{array}{l}\text { Does not provide a } \\
\text { modular API. It is } \\
\text { relatively hard to } \\
\text { extend }\end{array}$ \\
\hline PyKrige $^{3}$ & $\begin{array}{l}\text { None; supports } \\
\text { only low- } \\
\text { dimensional (2D } \\
\text { and 3D) problems }\end{array}$ & $\begin{array}{l}\text { Limited; only } \\
\text { supports variogram } \\
\text { models }\end{array}$ & None & $\begin{array}{l}\text { A kriging package } \\
\text { related to geostatistics }\end{array}$ \\
\hline $\begin{array}{l}\text { Cornell- } \\
\mathrm{MOE}^{4}\end{array}$ & $\begin{array}{l}\text { Supports } \\
\text { parallelization }\end{array}$ & $\begin{array}{l}\text { Supports multi- } \\
\text { fidelity and a variety } \\
\text { of acquisition } \\
\text { functions }\end{array}$ & $\begin{array}{l}\text { Provides a web-based } \\
\text { graphic user interface } \\
\text { through docker } \\
\text { installation }\end{array}$ & $\begin{array}{l}\text { Its core is implemented } \\
\text { in } \mathrm{C}++, \text { which is hard } \\
\text { to modify and extend }\end{array}$ \\
\hline $\mathrm{GyOpt}^{5}$ & $\begin{array}{l}\text { Supports } \\
\text { parallelization }\end{array}$ & $\begin{array}{l}\text { Supports mixed type } \\
\text { of input variables }\end{array}$ & $\begin{array}{l}\text { Supports external } \\
\text { objective functions }\end{array}$ & No longer maintained \\
\hline GPflowOpt $^{6}$ & $\begin{array}{l}\text { Supports GPU } \\
\text { acceleration; } \\
\text { parallelization is } \\
\text { not implemented }\end{array}$ & $\begin{array}{l}\text { Provides a variety of } \\
\text { acquisition } \\
\text { functions; supports } \\
\text { multi-objective }\end{array}$ & $\begin{array}{l}\text { Includes some DOE } \\
\text { functions }\end{array}$ & Built on TensorFlow \\
\hline Emukit $^{7}$ & None & $\begin{array}{l}\text { Supports multi- } \\
\text { fidelity, mixed type } \\
\text { of input variables }\end{array}$ & $\begin{array}{l}\text { Supports sensitivity } \\
\text { analysis; provides } \\
\text { examples relevant to } \\
\text { engineering design }\end{array}$ & $\begin{array}{l}\text { Agnostic to the model } \\
\text { backend; needs to be } \\
\text { used with other } \\
\text { modeling software }\end{array}$ \\
\hline
\end{tabular}




\begin{tabular}{|l|l|l|l|l|}
\hline $\begin{array}{l}\text { BoTorch } \\
\text { and } \mathrm{Ax}^{9}\end{array}$ & $\begin{array}{l}\text { Supports GPU } \\
\text { acceleration and } \\
\text { parallelization }\end{array}$ & $\begin{array}{l}\text { Supports state-of- } \\
\text { the-art BO methods }\end{array}$ & None & $\begin{array}{l}\text { Built on PyTorch; Ax } \\
\text { provides different } \\
\text { levels of API; requires } \\
\text { a steep learning curve }\end{array}$ \\
\hline edbo $^{10}$ & $\begin{array}{l}\text { Parallelization is } \\
\text { possible but not } \\
\text { implemented }\end{array}$ & $\begin{array}{l}\text { Supports categorical } \\
\text { and mixed type } \\
\text { input variables }\end{array}$ & $\begin{array}{l}\text { Supports descriptor } \\
\text { preprocessing and } \\
\text { selection }\end{array}$ & $\begin{array}{l}\text { Demonstrated with } \\
\text { high throughput } \\
\text { experiments; built on } \\
\text { PyTorch; lack of clear } \\
\text { documentation }\end{array}$ \\
\hline $\mathrm{COMBO}^{11}$ & None & $\begin{array}{l}\text { Limited choices of } \\
\text { models and } \\
\text { acquisition } \\
\text { functions }\end{array}$ & None & $\begin{array}{l}\text { Used for computational } \\
\text { materials design; lack } \\
\text { of guided examples }\end{array}$ \\
\hline $\begin{array}{l}\text { sckit- } \\
\text { optimize }\end{array}$ & None & $\begin{array}{l}\text { Supports random } \\
\text { forest model in } \\
\text { addition to Gaussian } \\
\text { processes }\end{array}$ & $\begin{array}{l}\text { Provides some } \\
\text { visualization } \\
\text { capabilities }\end{array}$ & $\begin{array}{l}\text { Built on Scikit-Learn; } \\
\text { implementation can be } \\
\text { slow }\end{array}$ \\
\hline
\end{tabular}

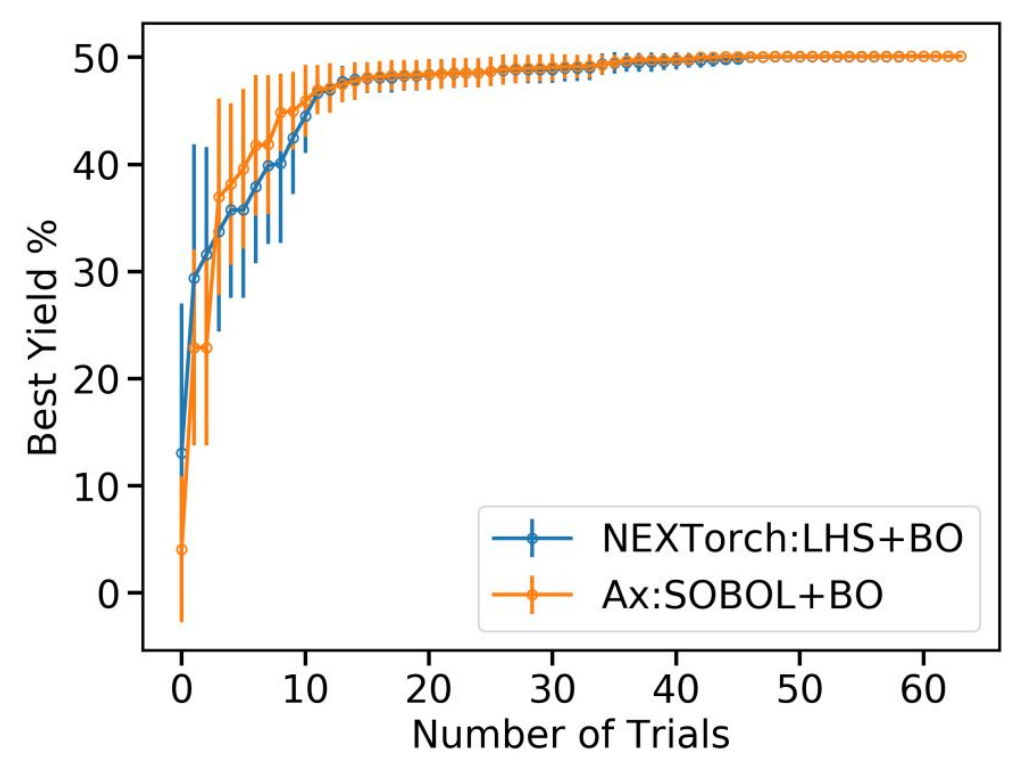

Figure S1. Comparison of the best yield value attained using LHS+BO in NEXTorch and SOBOL sequence (10 trials) + $\mathrm{BO}$ in $\mathrm{Ax}$. All curves are produced by averaging over 10 independent runs and error bars indicate the $95 \%$ confidence interval. Both methods converge to near-identical optima at similar rates.

\section{Multi-objective optimization (MOO)}

1. Weighted-sum method 


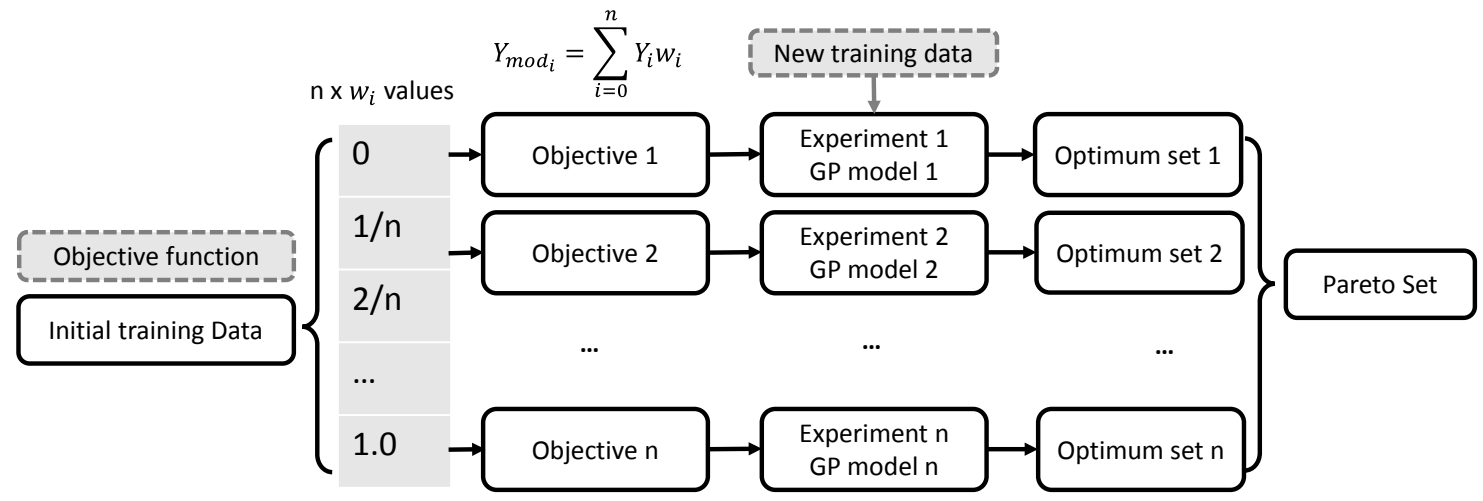

Figure S2. Scheme of weighted-sum method.

2. Expected hypervolume improvement (EHVI)

Given a Pareto set $S^{*}$ and a reference point $r \in \mathbb{R}^{M}$, the hypervolume (HV) of $S^{*}$ is the $M$-dimensional Lebesgue measure $\lambda_{M}$ of the region weakly dominated by $S^{*}$ and bounded above by $r^{13,14}$,

$H V\left(S^{*}\right)=\lambda_{M}\left(\cup_{p_{i} \in S}\left[r, p_{i}\right]\right)$

where $p_{i}$ is the $i$-th point in the $S^{*}$. Given a new set of points $S^{\prime}$, the hypervolume improvement (HVI) is defined as ${ }^{13,14}$,

$H V I\left(S^{\prime}, S^{*}\right)=H V\left(S^{*} \cup S^{\prime}\right)-H V\left(S^{*}\right)$

The examples of HV and HVI are shown in Figure S3. In this regard, for a set of points $\boldsymbol{X}$, the EHVI is the expectation of HVI over the posterior $\hat{f}$ and can be expressed as,

$\operatorname{EHVI}(\boldsymbol{X})=\mathbb{E}\left[H V I\left(\hat{f}(\boldsymbol{X}), \hat{f}\left(S^{*}\right)\right)\right]$
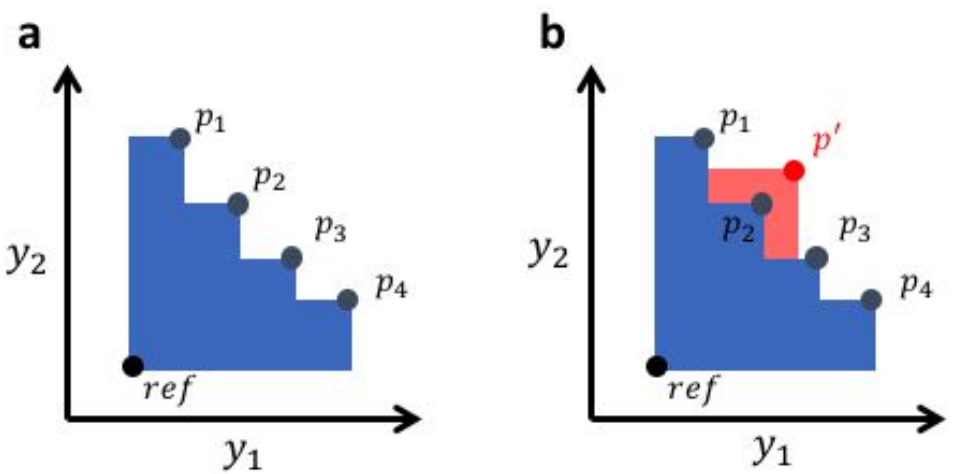

Figure S3. Scheme of MOO with two objectives (a) the HV (blue) of the set of $\left\{p_{1}, p_{2}, p_{3}, p_{4}\right\}$; and (b) the HVI (red) of the new point $\hat{f}\left(p^{\prime}\right)$. 
List of examples in the NEXTorch online documentation.

Table S2. List of examples in the NEXTorch online documentation.

\begin{tabular}{|c|c|c|c|c|c|}
\hline $\begin{array}{l}\text { Example } \\
\text { No. }\end{array}$ & Description & $\begin{array}{l}\text { Parameter(s) } \\
\text { (Type) }\end{array}$ & Objective(s) & $\begin{array}{l}\text { Experiment } \\
\text { Type }\end{array}$ & $\begin{array}{l}\text { Design(s) and } \\
\text { Workflow }\end{array}$ \\
\hline 1 & $\begin{array}{l}\text { 1-dimensional } \\
\text { nonlinear function }\end{array}$ & $x$ (continuous) & Minimize $y$ & Computational & Grid search \\
\hline 2 & $\begin{array}{l}\text { 1-dimensional } \\
\sin (\mathrm{x})\end{array}$ & $x$ (continuous) & Maximize $y$ & Computational & $\begin{array}{l}\text { Random } \\
\text { sampling }\end{array}$ \\
\hline 3 & $\begin{array}{l}\text { Langmuir } \\
\text { Hinshelwood } \\
\text { mechanism for a } \\
\text { bimolecular } \\
\text { reaction }\end{array}$ & $\begin{array}{l}\text { Pressures of } \\
\text { two species } \\
\text { (continuous) }\end{array}$ & $\begin{array}{l}\text { Maximize the } \\
\text { rate }\end{array}$ & Computational & $\begin{array}{l}\text { Full factorial and } \\
\text { LHS }\end{array}$ \\
\hline 4 & $\begin{array}{l}\text { Nitrogen-doped } \\
\text { carbon catalysts }\end{array}$ & $\begin{array}{l}\text { Synthesis } \\
\text { conditions } \\
\text { (continuous) }\end{array}$ & $\begin{array}{l}\text { Maximize the } \\
\text { catalyst } \\
\text { nitrogen content }\end{array}$ & Experimental & $\begin{array}{l}\text { LHS and human- } \\
\text { in-the-loop }\end{array}$ \\
\hline 5 & $\begin{array}{l}\text { 5-hydroxyl } \\
\text { methyl furfural } \\
\text { (HMF) production } \\
\text { in fructose } \\
\text { dehydration in a } \\
\text { PFR }\end{array}$ & $\begin{array}{l}\text { Reaction } \\
\text { conditions } \\
\text { (continuous) }\end{array}$ & $\begin{array}{l}\text { Maximize the } \\
\text { HMF yield }\end{array}$ & Computational & $\begin{array}{l}\text { Full factorial, } \\
\text { LHS, and } \\
\text { random sampling }\end{array}$ \\
\hline 6 & $\begin{array}{l}\text { MOO for an } \\
\text { ellipse function }\end{array}$ & $x$ (continuous) & $\begin{array}{l}\text { Maximize } y_{1} \\
\text { and } y_{2}\end{array}$ & Computational & LHS \\
\hline 7 & $\begin{array}{l}\text { MOO for PFR } \\
\text { using the } \\
\text { weighted sum } \\
\text { method }\end{array}$ & $\begin{array}{l}\text { Reaction } \\
\text { conditions } \\
\text { (continuous) }\end{array}$ & $\begin{array}{l}\text { Maximize the } \\
\text { HMF yield and } \\
\text { selectivity }\end{array}$ & Computational & LHS \\
\hline 8 & $\begin{array}{l}\text { Stub tuner of a } \\
\text { microwave cavity }\end{array}$ & $\begin{array}{l}\text { Length of } \\
\text { three stubs } \\
\text { (continuous) }\end{array}$ & $\begin{array}{l}\text { Maximize the } \\
\text { power } \\
\text { dissipation }\end{array}$ & Computational & $\begin{array}{l}\text { Full factorial } \\
\text { design and } \\
\text { integration with } \\
\text { automatic CFD } \\
\text { simulation }\end{array}$ \\
\hline 9 & $\begin{array}{l}\text { MOO for } \\
\text { microwave } \\
\text { operating } \\
\text { conditions }\end{array}$ & $\begin{array}{l}\text { Operating } \\
\text { conditions } \\
\text { (continuous) }\end{array}$ & $\begin{array}{l}\text { Maximize the } \\
\text { outlet } \\
\text { temperature and } \\
\text { efficiency }\end{array}$ & Computational & $\begin{array}{l}\text { Full factorial } \\
\text { design and } \\
\text { integration with } \\
\text { automatic CFD } \\
\text { simulation }\end{array}$ \\
\hline 10 & $\begin{array}{l}\text { PFR yield with } \\
\text { mixed type inputs }\end{array}$ & $\begin{array}{l}\text { Reaction } \\
\text { conditions } \\
\text { (mixed: } \\
\text { ordinal, } \\
\text { categorical, } \\
\text { continuous) }\end{array}$ & $\begin{array}{l}\text { Maximize the } \\
\text { HMF yield }\end{array}$ & Computational & $\begin{array}{l}\text { Random } \\
\text { sampling and } \\
\text { LHS }\end{array}$ \\
\hline
\end{tabular}




\begin{tabular}{|l|l|l|l|l|l|}
\hline 11 & $\begin{array}{l}\text { MOO for PFR } \\
\text { using qEHVI }\end{array}$ & $\begin{array}{l}\text { Reaction } \\
\text { conditions } \\
\text { (continuous) }\end{array}$ & $\begin{array}{l}\text { Maximize the } \\
\text { HMF yield and } \\
\text { selectivity }\end{array}$ & Computational & LHS \\
\hline 12 & $\begin{array}{l}\text { PFR yield with } \\
\text { different sampling } \\
\text { methods }\end{array}$ & $\begin{array}{l}\text { Reaction } \\
\text { conditions } \\
\text { (continuous) }\end{array}$ & $\begin{array}{l}\text { Maximize the } \\
\text { HMF yield }\end{array}$ & Computational & $\begin{array}{l}\text { Full factorial, } \\
\text { LHS+BO, } \\
\text { random } \\
\text { sampling, } \\
\text { SOBOL } \\
\text { sequence, box } \\
\text { Behnken, central } \\
\text { composite } \\
\text { design, and } \\
\text { SOBOL+BO in } \\
\text { Ax. Results are } \\
\text { shown in Figures } \\
\text { S1 and S5. }\end{array}$ \\
\hline 13 & $\begin{array}{l}\text { PFR yield using } \\
\text { Ax }\end{array}$ & $\begin{array}{l}\text { Reaction } \\
\text { conditions } \\
\text { (continuous) }\end{array}$ & $\begin{array}{l}\text { Maximize the } \\
\text { HMF yield }\end{array}$ & Computational & SOBOL + BO. \\
& & & & \\
\hline
\end{tabular}




\section{Optimization of HMF yield}

\section{Box-Behnken}
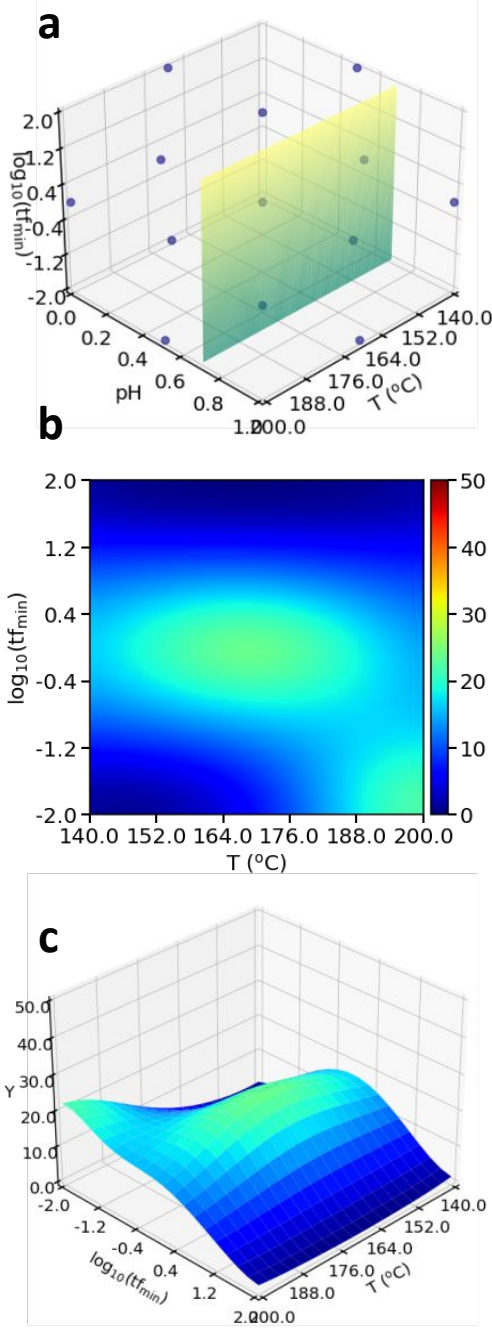

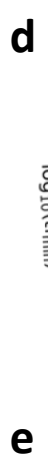

Central-Composite
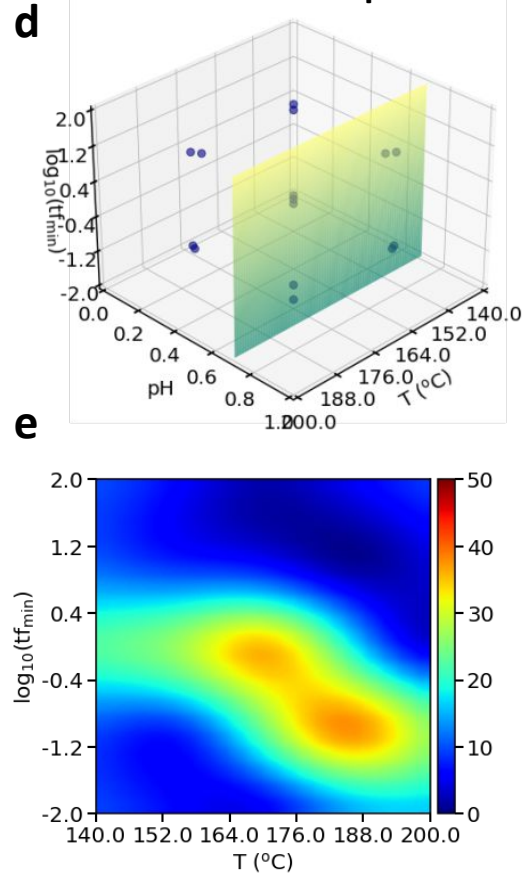

$\mathbf{f}$

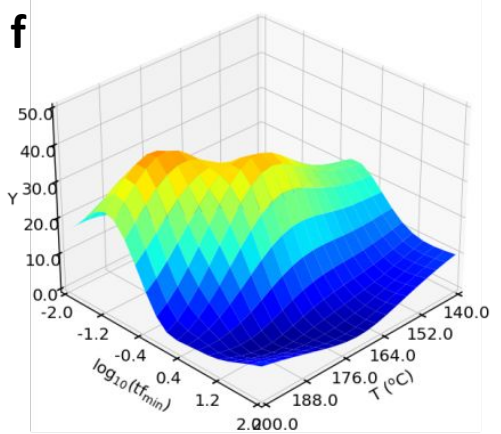

Sobol Sequence

g

h
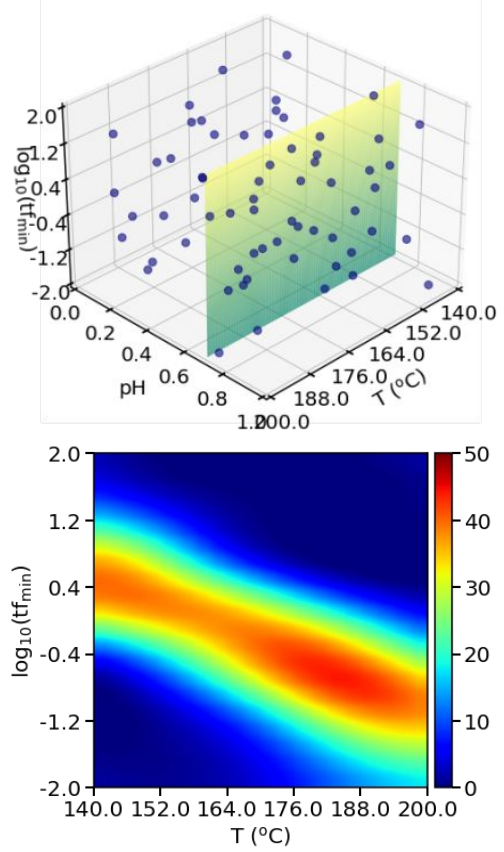

i

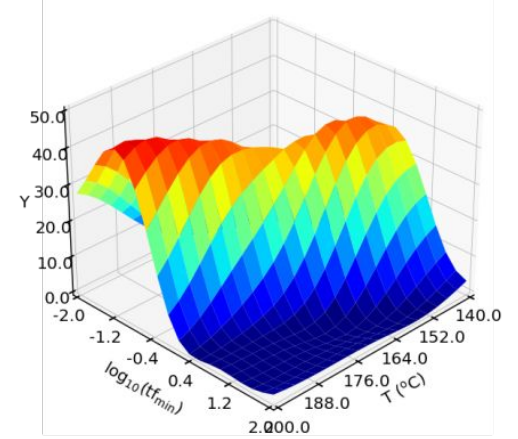

Figure S4. Optimization of HMF yield. (a) Sampling plan, (b) response surface, and (c) surface plot at pH $=0.7$ for the Box-Behnken approach. (d) Sampling plan, (e) response surface, and (f) surface plot at $\mathrm{pH}=$ 0.7 for the central composite approach. (g) Sampling plan, (h) response surface, and (i) surface plot at $\mathrm{pH}$ $=0.7$ for the Sobol sequence approach. In (d) and (g), the sampling points are visualized in three dimensions, and the two-dimensional plan at $\mathrm{pH}=0.7$ is shown in green. It is noted that the numbers of trials of box Behnken design and central composite design are 13 and 15, respectively, based on their sampling methodologies. 
Comparison of the best yield value attained using different sampling methods.

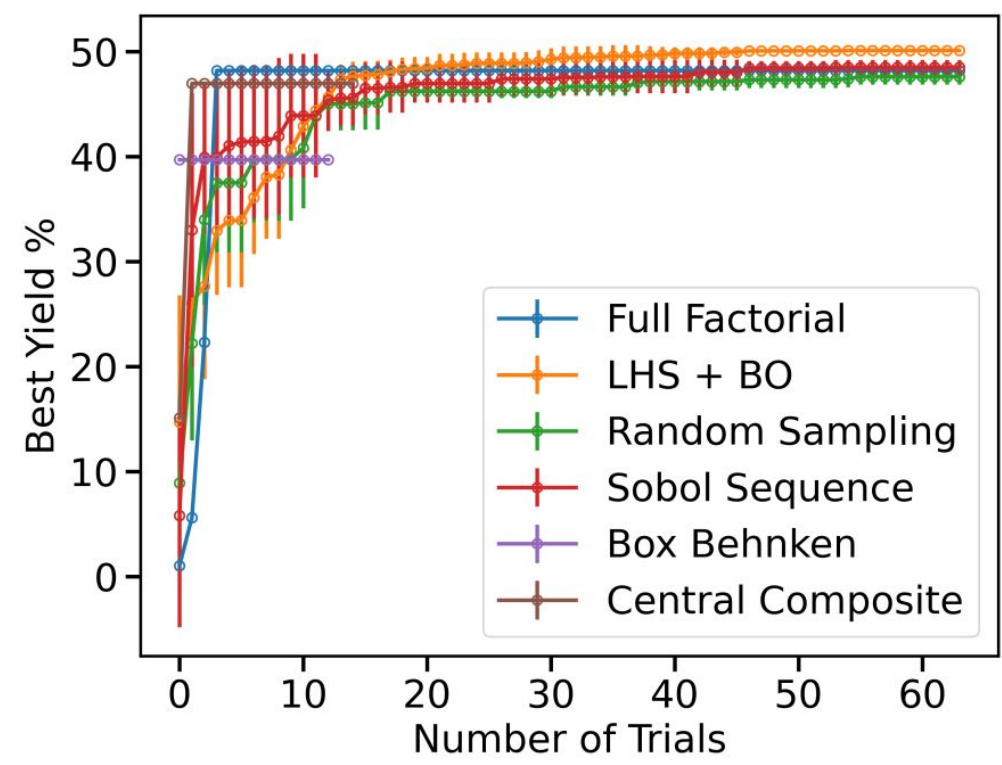

Figure S5. Comparison of the best yield value attained using full factorial, LHS+BO, random sampling, Sobol sequence, box Behnken, and central composite design indicated in different colors. All curves are produced by averaging over 10 independent runs and error bars indicate the $95 \%$ confidence interval. It is noted that the numbers of trials of box Behnken design and central composite design are 13 and 15 , respectively, based on their sampling methods.

Code examples for renewable platform chemical (HMF) yield optimization

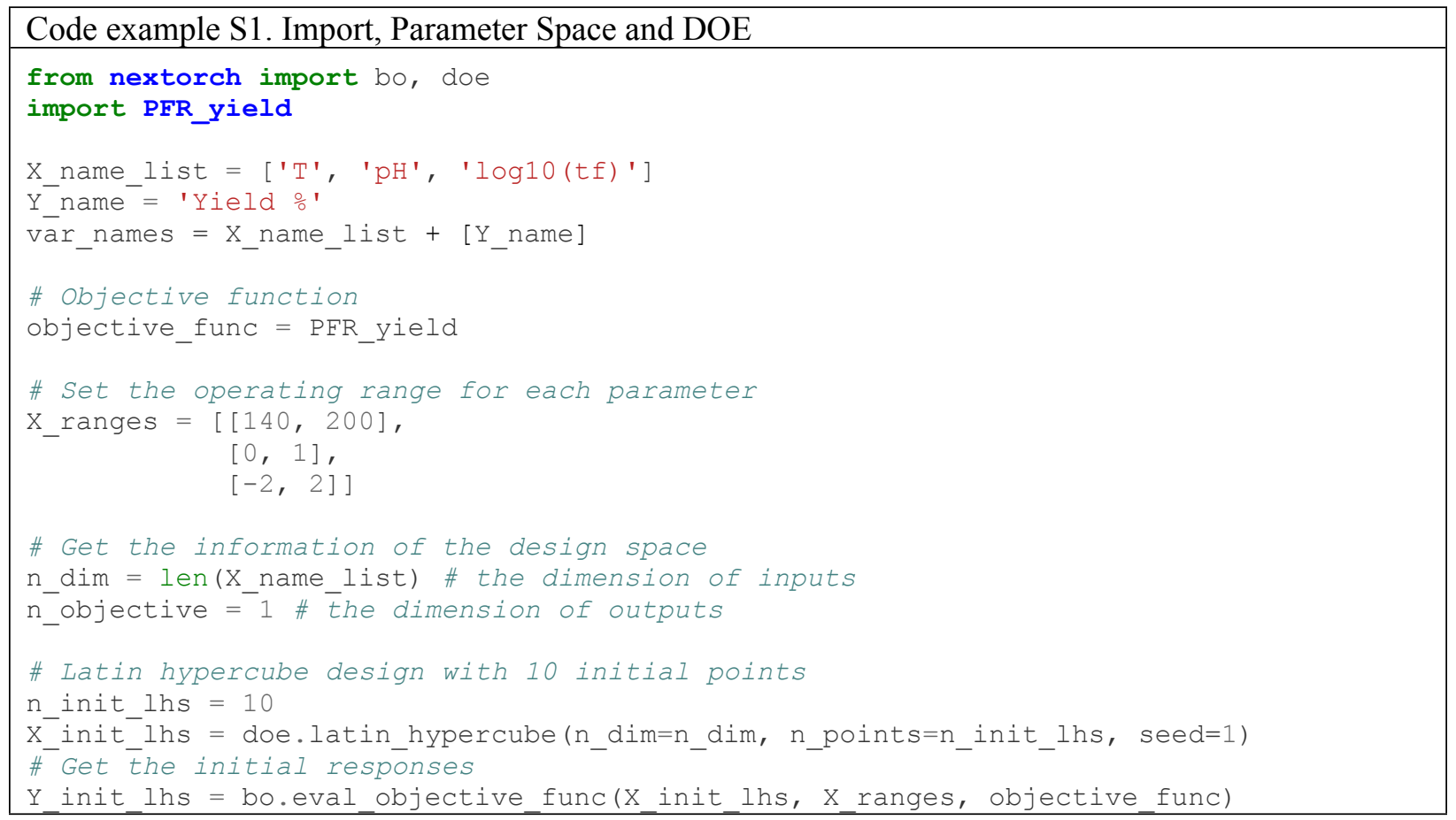




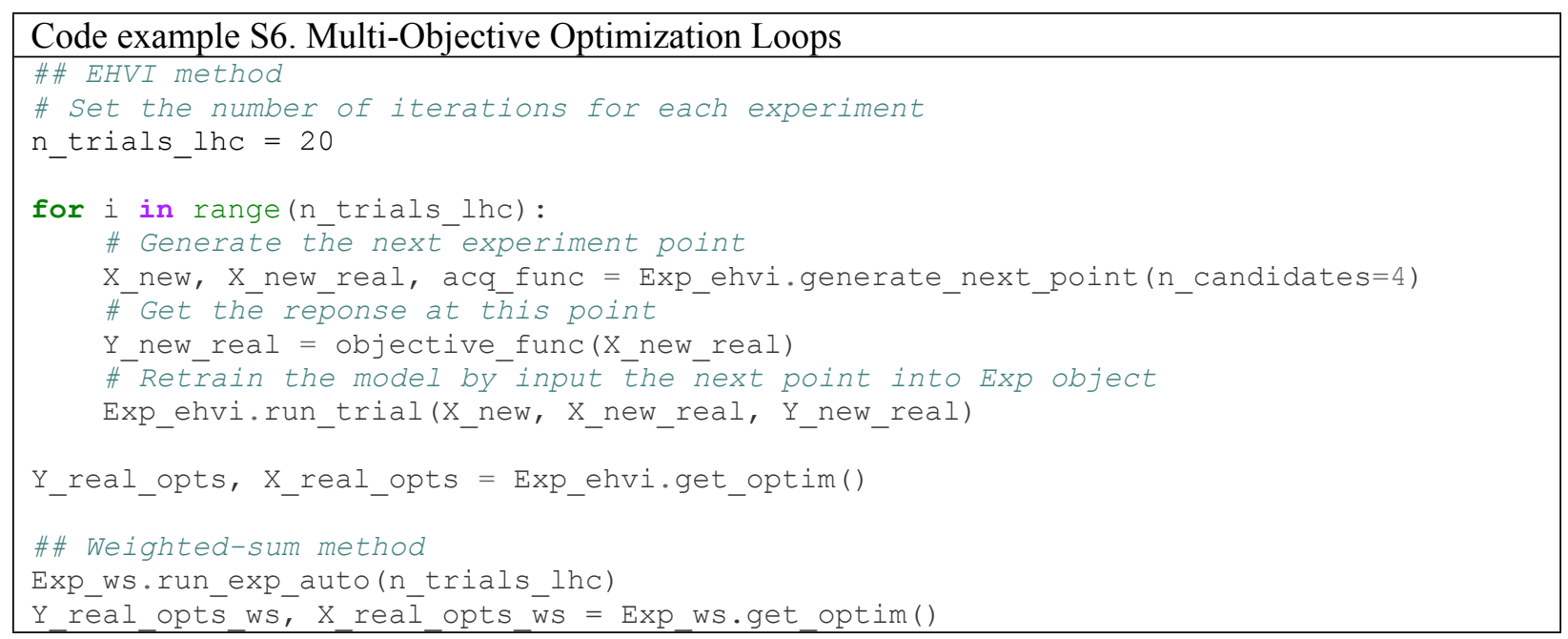

\section{References}

(1) Snoek, J.; Larochelle, H.; Adams, R. P. Practical Bayesian Optimization of Machine Learning Algorithms. 2012, 1-12.

(2) Kandasamy, K.; Vysyaraju, K. R.; Neiswanger, W.; Paria, B.; Collins, C. R.; Schneider, J.; Poczos, B.; Xing, E. P. Tuning Hyperparameters without Grad Students: Scalable and Robust Bayesian Optimisation with Dragonfly. 2019.

(3) Murphy, B.; Müller, S.; Yurchak, R. GeoStat-Framework/PyKrige v1.5.1. 2020.

(4) Wu, J.; Frazier, P. I. The Parallel Knowledge Gradient Method for Batch Bayesian Optimization. Adv. Neural Inf. Process. Syst. 2016, (Nips) No. Nips, 3134-3142.

(5) GPyOpt. GPyOpt: A Bayesian Optimization framework in python http://github.com/SheffieldML/GPyOpt.

(6) Knudde, N.; Van Der Herten, J.; Dhaene, T.; Couckuyt, I. GPflowOpt: A Bayesian Optimization Library Using TensorFlow. arXiv 2017, 0-1.

(7) Paleyes, A.; Pullin, M.; Mahsereci, M.; Lawrence, N.; Gonzalez, J. Emulation of Physical Processes with Emukit. NeurIPS 2019, (iii) No. iii.

(8) Balandat, M.; Karrer, B.; Jiang, D. R.; Daulton, S.; Letham, B.; Wilson, A. G.; Bakshy, E. BoTorch: A Framework for Efficient Monte-Carlo Bayesian Optimization. 2019.

(9) Facebook. Ax (Adaptive Experimentation Platform) https://ax.dev/.

(10) Shields, B. J.; Stevens, J.; Li, J.; Parasram, M.; Damani, F.; Alvarado, J. I. M.; Janey, J. M.; Adams, R. P.; Doyle, A. G. Bayesian Reaction Optimization as a Tool for Chemical Synthesis. Nature 2021, 590, 89-96.

(11) Ueno, T.; Rhone, T. D.; Hou, Z.; Mizoguchi, T.; Tsuda, K. COMBO: An Efficient Bayesian Optimization Library for Materials Science. Mater. Discov. 2016, 4, 18-21.

(12) Head, T.; Kumar, M.; Nahrstaedt, H.; Louppe, G.; Shcherbatyi, I. Scikit-Optimize/ScikitOptimize. 2020.

(13) Yang, K.; Emmerich, M.; Deutz, A.; Bäck, T. Multi-Objective Bayesian Global Optimization 
Using Expected Hypervolume Improvement Gradient. Swarm Evol. Comput. 2019, 44, 945-956.

(14) Daulton, S.; Balandat, M.; Bakshy, E. Differentiable Expected Hypervolume Improvement for Parallel Multi-Objective Bayesian Optimization. 2020. 